\title{
Habitat Quality in Association with Herd Health in Two Bighorn Sheep (Ovis canadensis canadensis) Populations
}

\author{
Rebecca K. Frey ${ }^{1}$, Alton C. S. Ward ${ }^{2}$ and Glen C. Weiser ${ }^{3}$ \\ ${ }^{1}$ United States Department of Agriculture, Animal and Plant Health Inspection Service, Veterinary \\ Services, Emigrant, Montana, USA \\ ${ }^{2,3}$ University of Idaho, Caine Veterinary Teaching Center, Caldwell, USA
}

Correspondence should be addressed to: Glen C. Weiser; Gweiser@uidaho.edu

Received date: 3 March 2015; Accepted date: 25 May 2015; Published date: 23 December 2015

Academic Editor: David Miller

Copyright (C) 2015. Rebecca K. Frey, Alton C. S. Ward and Glen C. Weiser. Distributed under Creative Commons CC-BY 4.0

\begin{abstract}
Multiple factors have been identified as elements of the respiratory disease complex in Rocky Mountain bighorn sheep (Ovis canadensis canadensis). We hypothesized that differences in health factors and Pasteurellaceae in the upper respiratory tracts could exist between populations of bighorn sheep with and without histories of pneumonic epizootics. We evaluated bighorn sheep in the Big Creek area of Central Idaho which had a history of respiratory disease, and hunter-harvested bighorn sheep from the Montana Spanish Peaks Range which had no history of respiratory disease. Factors evaluated included Pasteurellaceae, indicators of exposure to respiratory viruses, lungworm (Protostongylus spp.) loads, nutritional status and forage nutrient availability. Pasteurellaceae were isolated from both populations; however, significant differences $(\mathrm{P}<0.01)$ in $\beta$-hemolysis and cytotoxicity were detected between isolates from the two populations; $64 \%$ of isolates cultured from Idaho were $\beta$-hemolytic and $38 \%$ of those produced $>50 \%$ cytotoxicity. In contrast, $19 \%$ of the isolates from Montana were $\beta$ hemolytic and none of those produced cytotoxicity $>50 \%$. Low serum antibody titers against bovine viral diarrhea, and bovine respiratory syncytial virus were detected in Idaho bighorn sheep following a pneumonic epizootic and in both herds against parainfluenza-3 virus. Low lungworm loads were detected in both herds. Forage nutrient values were similar for the two populations; however, the selenium level present in the Montana forage was significantly higher $(\mathrm{P}=0.06)$ than that detected in the Idaho forage. It is concluded that variances in Pasteurellaceae virulence factors and dietary selenium, important in immune function, may be critical factors to consider when identifying conditions favoring a pneumonic epizootic.
\end{abstract}

Keywords: Ovis canadensis canadensis, habitat quality, herd health, respiratory disease

Cite this Article as: Rebecca K. Frey, Alton C. S. Ward and Glen C. Weiser (2015), " Habitat Quality in Association with Herd Health in Two Bighorn Sheep (Ovis canadensis canadensis) Populations", International Journal of Veterinary Medicine: Research \& Reports, Vol. 2015 (2015), Article ID 832408, 


\section{Introduction}

Respiratory disease has been a major mortality factor in Rocky Mountain bighorn sheep (Ovis canadensis canadensis) populations in North America and has been implicated as the major cause of population declines since the 1800's (Rush, 1927, Beuchner, 1960, Post 1962, Stelfox, 1971, Schwantje, 1988). Disease epizootics can progress rapidly and affect all ages of animals resulting in massive die-offs and reduced lamb recruitment for years afterward (Potts, 1937, Marsh, 1938, Spraker et al., 1984, Thorne et al., 1982).

Bacteria in the family Pasteurellaceae, primarily Mannheimia (Pasteurella) haemolytica, Bibersteinia trehalosi, and $P$. multocida have been implicated as critical pathogens associated with pneumonic epizootics in bighorn sheep (Schwantje, 1988, Rudolph et al. 2003, Weiser et al., 2003). A portion of the organisms previously identified as Pasteurella haemolytica have been assigned to the new genus Mannheimia using primarily $16 \mathrm{~S}$ rRNA sequencing along with other molecular tools (Angen et al. 1999). The isolates assigned to Mannheimia in the Angen study all originated in domestic animals. Most closely related organisms isolated from wildlife have some serological and biochemical utilization differences with regard to many domestic animal isolates (Jaworski et al., 1998).

Factors in addition to Pasteurellaceae are thought to contribute to the development of pneumonia in bighorn sheep. These factors include viral infections, (Spraker \& Collins, 1986, Parks et al., 1972), infection with Mycoplasma species (Rudolph et al., 2007, Besser et al., 2008), parasite loads (Thorne et al., 1982, Beuchner, 1960), poor habitat or nutrition (Stabel et al., 1993, Dunbar, 1992), overt stress (Spraker et al., 1984) and competition from other ungulates (McCoullough et al., 1980, Beuchner, 1960).

In most instances, investigation into herd health takes place after a die-off of bighorn sheep becomes evident as a means to diagnose and chronicle the course of the disease. However, there is no practical treatment for pneumonic respiratory disease in free-ranging bighorn sheep, and a better way to mediate its effects may be through proactive management. This might include periodic monitoring of herds for not only population management factors but also for risk factors associated with respiratory disease, as well as creating trigger values for mitigation events. A trigger value may be set in order to create consistent reactions to specific events throughout bighorn sheep management areas. For example, a reaction might include starting parasite therapy after annual fecal lungworm counts exceed 500 larvae per gram.

This study evaluated samples from two bighorn populations collected between September 1997 and May 2000. One population, Big Creek, Idaho (BC) was recovering from a major pneumonia die-off that occurred between 1989 and 1991 and the other, Spanish Peaks, Montana (SP) had no history of pneumonic respiratory disease. Data collected during the study were compared to data collected from Idaho bighorn sheep during a1989-1991 pneumonic epizootic (BCO), and 1994-1995 (BCR), considered a recovery period. This information was obtained in part from the Idaho Department of Fish \& Game Wildlife Laboratory, Caldwell, Idaho records. From 1997 to 2000, bacteriology, virology, serology, blood chemistries, parasitology and diet nutrient analysis, were performed concurrently in both populations to determine the health status of each population and look for differences that might alert wildlife managers of indicators of increased susceptibility to pneumonia. Evaluation of the results and comparison of health profiles may help identify risk factors associated with pneumonic respiratory disease in bighorn sheep and provide managers insight for proactive health management through this research. The objectives were: 1 . to test bighorn sheep in two populations for Pasteurellaceae and 
respiratory viruses, serum antibodies against respiratory viruses, intestinal parasites, blood chemistry profiles, and their habitats for forage availability and quality, 2. to compare the results of evaluations for the healthy SP population with those from bighorn sheep in the $\mathrm{BC}$ herd of central Idaho which has a history of respiratory disease, and 3. identify factors associated with increased potential for respiratory disease in the bighorn sheep.

\section{Materials and Methods}

Bighorn sheep: Free-ranging Rocky Mountain bighorn sheep were sampled from two populations: 14 (2 rams, 7 ewes, 5 lambs) from the Big Creek (BC) drainage population of Central Idaho and 15 rams from the Spanish Peaks (SP) Montana population. Big Creek sheep were captured by either immobilization $(n=5)$ with a combination of Xylazine/Ketamine (dosage: $1.5 \mathrm{mg} / \mathrm{kg}$ zylazine, $100 \mathrm{mg} / \mathrm{ml}$ and $7.5 \mathrm{mg} / \mathrm{kg}$ ketamine, $200 \mathrm{mg} / \mathrm{ml}$ ) or Telazol/Zylazine (rehydrated Telazol with $100 \mathrm{mg} / \mathrm{ml}$ Xylazine to 120 $\mathrm{mg} / \mathrm{ml}$; dose: $1 \mathrm{ml} / 75 \mathrm{lbs}$ ), or by helicopter drive netting $(\mathrm{n}=9)$ from December 1998April 2000. Chemical immobilization of animals was reversed with Tolazaline at 1.5 $\mathrm{ml} / 75 \mathrm{lbs} \geq 60$ minutes post immobilization to allow time for metabolism of immobilization components. Samples collected from the SP population were from hunter-harvested rams taken during the 1997, 1998 and 1999 hunting seasons and one ram captured by clover trap in February 1999. The animals were examined for condition, external parasites, and injuries. Nasal (NA), oropharyngeal (OP) swab samples, blood or vitreous humor, and fecal samples were collected from each of the animals. All procedures on live animals strictly followed guidelines (University of Idaho, Animal Care and Use Committee, Protocol 8047, Bradley Williams, DVM, IACUC Representative).

Bacteriology: Oropharyngeal (OP) samples were obtained from live animals using AccuCulshure (Accu-Med Corporation,
Pleasantville, New York) collection systems; Precision Culture Collection and Transport Systems with charcoal. Amies modified medium (Precision Dynamics Corporation, San Fernando, California) was used to collect samples from hunter-harvested animals. Samples were express shipped to the University of Idaho Caine Veterinary Teaching Center (CVTC) where they were inoculated onto Columbia blood agar (Becton, Dickinson and Company, Sparks, Maryland) with 5\% ovine blood (CBA) and a CBA containing antibiotics (CBAA) selective for Pasteurellaceae within 72 hours of sampling (Jaworski et al., 1993). Inoculated media were placed in a $37^{\circ} \mathrm{C}$ incubator with $10 \% \mathrm{CO}_{2}$ for 24 hours. Cultures were examined for bacterial colonies with characteristics of Pasteurellaceae and a representative of each colony type was selected for further characterization. Color, size, texture and hemolytic activities were evaluated for each selected isolate. The genus, species and biovariants of the isolates were differentiated by established procedures (Biberstein et al., 1991, Jaworski et al., 1998, Angen et al., 2002). Pasteurellaceae isolates, cultured from samples collected from the Idaho bighorn sheep population during a 1989-90 die-off (n $=10)$ and 1990-94 $(\mathrm{n}=4)$ recovery period, identified as $\mathrm{BCO}$ and $\mathrm{BCR}$ respectively, were archived at CVTC and compared with isolates from samples collected during the 19982000 study.

Restriction fragment length polymorphism analysis: Isolates from the $\mathrm{BC}$ and $\mathrm{SP}$ populations and the archived BCO and BCR isolates identified in the same species and biovariants were subjected to restriction fragment-length polymorphism (RFLP) analysis to determine relatedness as previously described (Weiser et al., 2003). The DNA for RFLP analysis was isolated using the Gentra Puregene DNA isolation kit (Gentra Systems Inc., Minneapolis, Minnesota) and restricted with HaeIII instead of Hha 1 as described by Jaworski et al. (1993). Restriction fragment banding patterns were used to determine relationship 
indices of isolates from each herd by biovariant (Nei \& Li, 1979). A dendogram was created with the unweighed pair-group method using arithmetic averages (UPGAMA) cluster analysis of 32 isolates from the $\mathrm{BC}$ and SP herds (Sneath \& Sokal, 1973).

Polymerase chain reaction for the lktA gene: A polymerase chain reaction (PCR) to detect the presence of the $l k t \mathrm{~A}$ gene was used to evaluate isolates. Amplification of $l k t \mathrm{~A}$ was done following the methods of Fisher et al. (1999). Briefly, a $50 \mu \mathrm{l}$ reaction volume containing $1.0 \mu \mathrm{l}$ purified DNA from each isolate was amplified in 30 cycles, consisting of denaturing at $94^{\circ} \mathrm{C} 1 \mathrm{~min}$; annealing at $55^{\circ} \mathrm{C} 1 \mathrm{~min}$; and extension at $72^{\circ} \mathrm{C} 1 \mathrm{~min}$, were applied. Gels were stained with ethidium bromide for visualization of the lktA PCR product.

Leukotoxin cytotoxicity: Hemolytic, lktA positive isolates were propagated for leukotoxin detection by the methods of Shewen \& Wilkie (1986). Briefly, isolates were incubated in brain heart infusion (BHI) broth (Becton Dickinson and Company, Sparks, Maryland) for 16 hours, then suspended in RPMI 1640 (Sigma-Aldrich, St Louis, Missouri) containing 7\% fetal bovine serum and incubated at $37^{\circ} \mathrm{C}$ with shaking for one hour. The suspensions were then centrifuged and the harvested supernatants were tested by a colorimetric cytotoxicity assay as described by Greer \& Shewen (1986) using bovine BL3 lymphoma cells. Cytotoxicity was calculated by the determination of the percent of cells killed. Isolates which killed $>50 \%$ were considered virulent and those which killed $<50 \%$ were considered avirulent. A chi- square test was used to compare toxicity results of isolates between the herds (Moore \& McCabe, 1993).

Virology: Nasal samples were collected using Viral Culturette swab systems containing 0.5 ml modified Hank's balanced salt solution (HBSS) (Becton Dickinson \& Co., Cockeysville, Maryland) and sent to CVTC where they were prepared for inoculation onto cell monolayers for viral culture. Briefly, swabs were washed in $2 \mathrm{ml}$ HBSS, 200 $\mu \mathrm{l} /$ well of the HBSS extract was pipetted into wells of 24 well tissue culture plates containing 24 hour monolayers of bovine turbinate (BT) cells, bighorn sheep turbinate (BHST) cells, and bighorn sheep kidney (BHSK) cells (DeLong et al. 2000) and incubated at $370^{\circ} \mathrm{C}$ in an atmosphere containing $10 \% \quad \mathrm{CO}_{2}$. Cell cultures were examined at 1 to 2 day intervals for cytopathology for 10 days. Supernatant from each well was used to make two additional passages onto fresh monolayers and the final monolayer was stained with fluorescent labeled antisera to bovine viral diarrhea (BVD), infectious bovine rhinotracheitis (IBR), parainfluenza-3 (PI-3), bovine respiratory syncytial virus (BRSV) and adenoviruses and examined microscopically. Lack of fluorescence was reported as negative.

Serologic testing: Blood was collected into two $10.0 \mathrm{ml}$ tubes containing SST gel and clot activator and two $7.5 \mathrm{ml}$ tubes containing sodium heparin per animal (BC, $n=14$; $S P$, $\mathrm{n}=5$ ) using Vacutainer systems (Becton Dickinson Vacutainer Systems, Franklin Lakes, New Jersey). Clotted blood was centrifuged within 24 hours after collection at $2500 \mathrm{rpm}$ for 10 minutes to separate serum. Serum was decanted into $2.5 \mathrm{ml}$ tubes and sent to the Bureau of Animal Health Laboratory, Boise, Idaho for serologic testing. Tests included assays for antibodies against anaplasmosis, bluetongue (BT), BRSV, IBR, BVD, PI-3, epizootic hemorrhagic disease (EHD), and ovine progressive pneumonia (OPP) viruses, Brucella ovis, and leptospira serovars. A single BC sample was sent to the National Veterinary Service Laboratory (NVSL) in Ames, lowa where it was tested for antibodies against BRSV, IBR, BVD and PI-3.

Blood chemistry analysis: Heparinized blood was sent to the University of Idaho Analytical Sciences Laboratory, Holm Research Center, Moscow, Idaho for quantification of selenium (Se) levels. Vitreous humor, collected by aspiration from the eyes of hunter-harvested bighorns in the SP population and blood from 
all other animals were sent to the Treasure Valley Laboratory (TVL), Boise, Idaho for chemical analyses. Tests conducted at TVL included quantitation of blood urea nitrogen (BUN), creatinine, sodium (Na), potassium $(\mathrm{K})$, chloride $(\mathrm{Cl})$, calcium $(\mathrm{Ca})$, phosphorus (P). Mean blood chemistry values for each test and herd were evaluated on a herd basis.

Parasitology: Fecal samples were collected from the rectum of captured and killed animals (BC, $n=14 ; S P, n=5$ ) with a gloved hand and placed in sterile Whirl-Pak bags (Nasco Corporation, Ft. Atkinson, Wisconsin). Fecal samples were also obtained from the ground during periods of bighorn observation (BC, n=14; SP, n=13). Samples were submitted to CVTC and the Washington State University Parasitology Laboratory where they were evaluated with primary emphasis on the detection of Protostrongylus spp. using the Baermann procedure. Samples were also evaluated for other genera including Nematodirus, Coccidia and Trichuris. Baermann results were combined for each population and parasite loads were interpreted as recommended by Thorne et al. (1982).

Forage and habitat evaluation: Samples of forage available and forage utilized by bighorn sheep were collected to determine the nutritional quality of the forage on respective ranges. Samples were collected at four intervals representing spring/lambing (S) range, summer (SU) range, early winter/ breeding (W) range and late winter (W2) range for the SP and BC herds. Available forage was determined by observations of range areas being used by the sheep at the specified times. Forage was gathered from representative areas within the same habitat type predominantly used by the two herds by the method of Daubenmire (BLM-NARSC, 1986). The forage species and percentage of cover were identified in 12 two $\mathrm{ft}^{2}$ randomly selected plots. Forage was collected for analysis from five (also randomly selected) of those plots. The same five plots were collected for each interval and for each herd.
Diets were determined by binocular $(10 \mathrm{x}$ $25)$ or scopic $(10 \times 40)$ observation of sheep for periods of at least 10 minutes per animal and for one hour per group of sheep. Bites of individual species were recorded and confirmed through close observation of grazing area immediately following a grazing bout to identify freshly bitten plants. Representative samples of the eaten plants were collected and weighed immediately to determine fresh weights of the forage. Composition of diets was determined by estimating bites per species and obtaining percentages of total bites. Once collected and weighed, all samples were dried at $55^{\circ} \mathrm{C}$, reweighed, and ground to $\leq 4 \mathrm{~mm}$. All samples were then sent to Iowa Testing Laboratories, Inc., Ames, Iowa for total nutrient analysis and selenium testing. Values were obtained for each bighorn herd for the following parameters; acid digestible fiber (ADF), Calcium (Ca), Copper $(\mathrm{Cu})$, Iron $(\mathrm{Fe})$, metabolizable energy (ME), phosphorous (P), total protein (TP), digestible protein (DP), selenium (Se), total digestible nutrients (TDN), and Zinc (Zn). Differences in mean values between the two populations were tested with analysis of variance. Percentage data were transformed with arc sine square root before analysis (Snedecor, 1946).

\section{Results}

Bacteriology: Pasteurellaceae were cultured from 12 of 14 (86\%) Idaho BC and 11 of 15 (73\%) SP bighorn sheep during the study period (Tables 1 and 2). Multiple biovariants of B. trehalosi and Mannheimia spp. were isolated from both populations. Three biovariants of $B$. trehalosi, $2(\beta), 2(\mathrm{nh})$ and $4(\beta)$ and one non-speciated Mannheimia biovariant, $10^{\alpha \mathrm{B}}(\beta)$ were isolated from both populations. Bibersteinia isolated from 7 BCO, 2 BCR and 10 BC Idaho bighorn sheep in contrast to only two isolates from SP bighorn sheep produced beta-hemolysis.

Isolates from $1 \mathrm{BCO}, 2 \mathrm{BCR}$ and $1 \mathrm{SP}$ bighorn sheep were identified as M. glucosida. Although those from the Idaho bighorn sheep produced beta-hemolysis and were positive 
for the lktA gene, they were of low cytotoxicity (Table 2). The M. glucosida isolate from the SP ram did not produce hemolysis and was negative for the $l k t A$ gene. Isolates in nine biovariants were identified as $M$. ruminalis, seven of which were isolated from Idaho bighorn sheep and two from the SP population. Isolates in 4 of the 7 Idaho biovariants produced beta-hemolysis and tested positive for the lktA gene although only the biovariant $8(\beta)$ isolate produced cytotoxicity of $>50 \%$. Neither of the $M$. ruminalis biovariants isolated from the SP population produced beta-hemolysis nor did those tested produce cytotoxicity $>27 \%$. Isolates in seven and three additional biovariant groups, from Idaho and SP populations respectively were not phenotyically speciated (Angen et al., 2002). Two non-speciated isolates, one $\mathrm{BCO}$ and one SP, were identified in biovariant group $10^{\alpha \mathrm{B}}$ $(\beta)$ tested positive for the $l k t A$ gene but were of low cytoxicity. In addition, P. multocida subsp. gallicida was cultured from one of the SP bighorn sheep.

Detection of the lktA gene by PCR and Leukotoxin Analysis: A total of 53 isolates (15 SP, 7 BCO, 5 BCR and 26 BC) were tested by PCR for the lktA gene (Table 1). Six (86\%) BCO, 4 (100\%) BCR and 23 (89\%) BC isolates were positive for the lktA gene. In contrast, only 8 of 15 (53\%) SP isolates were positive for the lktA gene. Four of eight lktA positive BCO isolates, produced $>50 \%$ toxicity (76$83 \%$ ) with a mean of $80 \%$. Similarly, 8 of 21 (38\%) of BC lktA gene-positive isolates tested $>50 \%$ toxicity with a range of $56-96 \%$ toxicity. A B. trehalosi (99-302-1) isolated from a BC ram lamb exhibited the highest (96\%) toxicity. The cytotoxicity of BCO and BC lktA positive isolates did not differ significantly ( $p>0.25$ ), but those isolates were significantly more toxic than those from the SP herd ( $\mathrm{p}<0.01)$ which ranged from 0 $27 \%$ with a mean of $7 \%$ toxicity.

Restriction Fragment Length Polymorphism Pattern Analysis: The B. trehalosi 2(nh), $2(\beta)$ and $4(\beta)$ biovariants and Mannheimia spp. biovariant $10^{\alpha \mathrm{B}}(\beta)$ which were cultured from both the Idaho and Montana bighorn sheep populations varied by RFLP patterns. A dendrogram generated from RFLP profiles of 32 isolates contained 2 main clusters, of nearly equal size (Figure 1). Cluster A, generated from profiles of $179 \mathrm{SP}, 6 \mathrm{BC}$ and 2 BCO RFLP profiles has 3 subclusters. The RFLP of a non-hemolytic $M$. ruminalis $\mathrm{BC}$ biovariant $1^{\alpha \mathrm{B}}$ isolate, (00-608-22) in subcluster $\mathrm{A}^{1}$ was distinctly different from those of all other isolates. Of the remaining 16 isolates in cluster A, 14 had similarity coefficient (SC) values $>0.8$. In 3 instances, 1 involving 2 SP isolates (99-200-2 and 991375-2) in subcluster $A^{2}$ and 2 involving 2 groups of BC isolates (00-608-52, 98-162110 and 00-608-32) and (00-608-101 and 00608-92) in subcluster $A^{3}$, the RFLP profiles of isolates in each of the groups were identical with SC values of 1.0 .

All RFLP profiles represented in cluster B were from Idaho bighorn sheep isolates; BCO $(n=6)$, BCR $(n=2)$ and BC $(n=7)$, (Figure 1). The RFLP profiles of two B. trehalosi isolates; BCR 94-1499-3 and BC 99-319-1 had SC values of $<0.5$ compared with the other six isolates in subcluster $\mathrm{B}^{1}$. The RFLP profiles of 4 isolates; BCO 89-269, BC99-302-1, BC 00608-94 and BC 00-608-113 isolates identified as $B$. trehalosi in biovariant 2, produced beta-hemolysis and had SC values $>0.8$. Isolate BCR 95-622-3 which clustered with those four isolates was identified as $M$. glucosida but on subsequent subculture was found to have been mixed with $B$. trehalosi in initial test procedures including RFLP testing.

Beta-hemolytic and non-hemolytic $B$. trehalosi biovariant 2 isolates from the Idaho bighorn sheep had markedly differing RFLP patterns. However, SP isolates identified in hemolytic and non-hemolytic biovariants 2 and non-hemolytic biovariants $4^{\mathrm{s}}$ produced remarkably similar RFLP patterns. Eight of the nine isolates from Idaho bighorn sheep with leukotoxin cytotoxicity readings $>50 \%$ were evenly divided between subclusters $\mathrm{B}^{1}$ and $\mathrm{B}^{2}$. None of the SP samples had cytotoxicity readings $>50 \%$. 
Virology: Viruses were not isolated from any of the samples $(\mathrm{BC}=14, \mathrm{BCO}=5, \mathrm{SP}=15)$, and all fluorescent antibody tests were negative for the targeted viruses.

Serology test result: Serologic tests were predominantly negative for antibodies against BRSV, BVD, IBR, PI-3 and OPP (Table 3). All BCO serum samples tested negative for antibodies against these respiratory viruses. However, antibodies were detected in all five BCR serum samples, five of which had antibodies against BRSV, four tested positive for antibodies against BVD and four tested positive for antibodies against PI-3. One BC and one SP sample had antibodies against PI3 in the 1:32 and 1:8 serum dilutions respectively. None of the samples tested positive for antibodies against IBR or OPP viruses. One $\mathrm{BC}$ and one SP sample were toxic in tests for antibodies against BRSV, BVD, IBR and PI-3 resulting in no data against those organisms. Two of four samples collected from BCO bighorn sheep had antibodies detected against $L$. pomona antigens in the 1:50 dilutions. Three BC samples tested positive for antibodies against Anaplasma marginale at the lowest dilution tested (1:5), three samples tested positive in the 1:50 dilution against Leptospira ballum $(\mathrm{n}=1)$, L. bratislava $(\mathrm{n}=$ $2)$, and L. pomona $(\mathrm{n}=1)$ antigen. One SP serum tested positive for antibodies against Leptospira bratislava $(1: 50)$ and $L$. canicola (1:100). Two other SP serum samples had low titers against $A$. marginale.

Parasitology: Baermann test results for Protostongylus spp. gave a mean larvae/gram (LPG) of 23 from BC, with the highest individual shedding of $168 \mathrm{LPG}$, and a mean of 57 LPG from SP, with the highest individual shedding 512 LPG. No individuals had high lungworm loads, and neither herd showed a high lungworm infestation on a pooled basis. No parasitology results were available from individual sheep from BCO. Differential shedding was apparent in the samples for both herds based on time of collection, where those from the summer range $(\mathrm{BC}=0.33 \mathrm{LPG}$; $\mathrm{SP}=0.33 \mathrm{LPG}$ ) were lower than those from the winter range $(\mathrm{BC}=$ 56 LPG; SP = 101 LPG). Lungworm loads were also noticeably higher during late winter periods than early winter $(\mathrm{BC}=84$ and 29 LPG; SP = 118 and 84 LPG) although this may be confounded due to intermittent shedding.

Blood and vitreous humor chemistry test results: Results of tests conducted on blood samples from the Idaho bighorn sheep and vitreous humor samples from SP bighorns are presented with normal blood values for domestic sheep (NRC, 1985) in Table 4. Some animals in each group tested high for BUN, Creatinine, $\mathrm{Na}, \mathrm{K}$, and $\mathrm{Cl}$. In contrast, all but one sample had low Ca levels and some were low for P. Whole blood selenium (Se) levels for the $\mathrm{BCO}$ and $\mathrm{BC}$ populations ranged from $<0.01-0.05$ with a mean of $0.036 \mathrm{ppm}$ and $0.011-0.15 \mathrm{ppm}$ with a mean of $0.045 \mathrm{ppm}$ respectively. Blood Se data were not available for the SP herd.

Forage and Habitat Evaluation: Domestic sheep nutritional requirements (NRC, 1985) were used for comparison with results of forage composition collected from bighorn sheep ranges (Table 5). Percent nitrogen and protein mean values of diet and random samples collected from both the BC and SP ranges exceeded those recommended for domestic sheep. Mean percentage Ca values were high in forage from both habitats with that of the SP range being four times the recommended level in domestic sheep diets. The mean phosphorus level in the $\mathrm{BC}$ forage was $143 \%$ higher than that of the SP forage and 125\% higher than the NRC (1985) domestic sheep requirement. In contrast, magnesium in the SP forage was $120 \%$ of that in the $\mathrm{BC}$ forage and slightly greater than the listed domestic sheep requirement. Manganese ppm in both the BC and SP forage were greater than required for domestic sheep. And while the copper ppm values were in the normal range iron ppm values in forage from both ranges were much higher than recommended for domestic sheep and selenium ppm values were considerably lower than recommended with that of the $\mathrm{BC}$ 
forage significantly lower $(\mathrm{p}=0.06)$ than that of the SP forage. Total digestible nutrients and metabolizable energy values were comparable to those recommended for domestic sheep.

\section{Discussion}

Pasteurellaceae are normally present as commensal organisms in the upper respiratory tract of bighorn sheep (Queen et al., 1989, Ward et al., 1997). Failure to isolate members of this group of bacteria from two $\mathrm{BC}$ and four SP samples could have resulted from several factors. Unavoidable delays between the time of death of hunter harvested animals and the time of sample collection, difficulty accessing the tonsillar crypt area of live animals, and duration between the time of sample collection and arrival at the laboratory for initiation of bacterial culture procedures, would all adversely affect culture results. (Walsh et al., 2012)

Pasteurellaceae isolated from both the Idaho and Montana bighorn sheep were quite diverse being identified in the biovariants of B. trehalosi, M. glucosida, M. ruminalis and non-speciated Mannheimia as well as $P$. multocida subspecies gallicida. Pasteurellaceae identified in beta hemolytic B. trehalosi biovariants 2 and 4 , a non speciated Mannheimia biovariant $10^{\alpha \mathrm{B}}$ and non-hemolytic $B$. trehalosi biovariant 2 were isolated from both Idaho and Montana bighorn sheep. However, by subsequent testing the isolates were found to differ by RFLP patterns, possession of the lktA gene and leukotoxin activities. It could therefore be concluded that each population had unique Pasteurellaceae profiles. Possession of the lktA gene has been associated with beta-hemolytic activity and leukotoxin production (Fisher et al. 1999) and in some instances with respiratory disease in bighorn sheep (Jaworski et al., 1993, Miller et al., 2012). Although some isolates from the Montana SP population were positive for the IktA gene, they had very low cytotoxicity activity and therefore less virulent. Multiple
lktA gene alleles have been identified (Kelley et al., 2007) and may account for variances in cytotoxicity and virulence in bighorn sheep. If leukotoxin is a primary factor involved in the development of pneumonia, differences of cytotoxicity of the Pasteurellaceae carried by a herd may be associated with incidence and severity of the disease in that population.

All SP RFLP profiles were grouped in cluster A of the dendrogram and although eight Idaho isolates had RFLP profiles similar with SP isolates and were included in cluster A, they varied in other characteristics. One of the BCO isolates (89-269) and two BC isolates (99-302-1 and 00-608-94) had RFLP profiles with similarity coefficient (SC) values of 1.0 with the isolates cultured from transtracheal wash samples of bighorn lambs with respiratory disease (Jaworski et al., 1993). Isolates BC 00-608-113 had a SC value $>0.9$, generally considered indicative of close identity with the previously listed isolates. Isolates 99-302-1, 00-698-94 and 00-608113 produced $96 \%, 72 \%$ and $56 \%$ cytotoxicity respectively. Based on the RFLP profiles, this strain had been present in Idaho bighorn sheep populations without discernible genetic variation for more than a decade. All of the RFLP patterns of those isolates were grouped in cluster B of the dendrogram. In contrast, the RFLP patterns of the beta-hemolytic biovariant 2 isolates from SP bighorn sheep were separated into cluster A and had SC values $<0.2$ indicating that they were very different genetically from the Idaho isolates.

Since viruses were not cultured from either herd and antibody titers against select respiratory viruses that were conducted on a limited number of sera from the two herds, the presence and role in health of the sheep in the two populations could not be adequately accessed. However, tests did detect antibodies against PI-3 in sera from both herds and BVD and RSV in the Idaho herd. Since acute and convalescent titers were not determined for any of the bighorns, it is not possible to determine if the titers represented new infections or residual 
antibodies from previous exposure. The presence of antibodies to BRSV, BVD and PI-3 in BCR bighorn serum samples is compatible with prior exposure that may have been associated with the 1989-1991 epizootic. Parks \& England (1974) detected antibody titers comparable to those detected in this study in bighorn sheep in Colorado and Wyoming. Respiratory viruses commonly play a role in pneumonic episodes by causing damage to the lung, allowing opportunistic pathogens such as Pasteurellaceae to infect the lungs (Brogden et al., 1998). Combined with virulent bacteria such as the cytotoxic $B$. trehalosi which appears to be endemic in the Idaho bighorn population, immunity could have been compromised by viruses thus leading to pneumonia associated with bacterial pathogens. Samples from these groups of bighorn sheep were not tested for the presence of Mycoplasma species or serum antibodies indicative of infection. Mycoplasma ovipneumoniae which may cause pneumonia alone or in association with Mannheimia and Bibersteinia species (Ruffin, 2001) has since been detected in multiple bighorn sheep populations (Rudolph et al., 2007, Weiser et al., 2012; Shanthalingam et al., 2014).

High parasite shedding was not detected in either herd. Although Protostrongylus spp. is associated with lung lesions, the number of this parasite detected in the two bighorn sheep populations was considered relatively low (Thorne et al., 1982). Factors which may have contributed to the low counts included low land snail numbers and low sheep density. These factors may also account for the seasonal variation in lungworm loads with low counts on summer range, when sheep were at lower density and higher elevations and higher counts when sheep were congregated on winter range. Supplemental feeding of fenbendazole pellets conducted annually to a small portion of the SP herd during 1988-1997 may have had a substantial effect on the lungworm shedding in that herd. The BC herd which was at a low population density compared to numbers prior to the 1989-1991 epizootic (Akenson \&
Akenson, 1992) had no history of being supplemented with de-worming medication.

Elevation of BUN, creatinine, $\mathrm{K}$ and $\mathrm{P}$ levels were detected in some blood samples of BC bighorn sheep in contrast to normal values reported for domestic sheep. Such high values may have resulted from the test results of nine bighorns that were caught by helicopter drive netting on one day. Those nine individuals averaged BUN and $\mathrm{P}$ values of 31 and 7.5 respectively, which are abnormally high and probably reflect hydration levels at the time of capture. If test results of those nine animals are eliminated, BUN and P levels for BC sheep would be 17.2 and 3.82 respectively. Although capture histories did not record dehydration or stress conditions associated with capture of the BCO bighorn sheep, similar stresses could have also influenced values in the blood of those bighorns. Blood levels of $\mathrm{Ca}$ and $\mathrm{P}$, which are critical for bone and teeth formation and numerous metabolically active compounds (NRC, 2005), were both low in $\mathrm{BCO}$ and BC bighorn groups although there was no evidence of impaired bone formation or energy levels of the animals.

Although the chemical components of serum and vitreous humor are not identical, testing of the vitreous humor does provide some information relative to the nutritional status of the animals tested (McLaughlin \& McLaughlin, 1987). They concluded that by expressing vitreous values as a ratio to serum values, the vitreous values could be interpreted in relationship to the expected serum values. When the ratio of the mean vitreous humor values of the SP bighorn sheep to the mean normal values for domestic sheep serum are calculated and compared to ratios of vitreous humor to serum collected from cattle at time of slaughter, similar ratios were observed with the exception of SP bighorn sheep values for BUN, $K$ and $P$ (Table 6). McLaughlin \& McLaughlin (1987) also found that $K$ and $P$ increased significantly $(\mathrm{P}<0.05)$ after $12 \mathrm{hrs}$ at $4^{\circ} \mathrm{C}$ while significant differences in BUN values did not occur at $4^{\circ}$ or $20^{\circ}$ at 12 hours 
but were detected at $37^{\circ} \mathrm{C}$. Vitreous humor was readily accessible in most hunter-killed bighorns; however, temperatures and times between death and collection of vitreous humor from the bighorn sheep varied and were therefore the most probable cause of the variances from expected vitreous to blood serum ratios.

Mean blood Se values of the $\mathrm{BCO}$ and $\mathrm{BC}$ bighorns appeared to be low in comparison to the normal levels of $0.05-0.12 \mathrm{ug} / \mathrm{g}$ published for domestic sheep (NRC, 1985). Although normal blood Se levels have not been determined for Rocky Mountain bighorn sheep, 0.005-1.60 ug/g have previously been reported (Samson et al., 1989). Rocky Mountain bighorn habitats tend to have low Se levels due to leeching from mountains through normal runoff (Robbins, 1993). Forage Se concentrations of 0.10 to $0.12 \mathrm{ppm}$ are recommended for domestic sheep and blood levels of $0.2 \mathrm{ug} / \mathrm{ml}$ are recommended for adequate Se transfer to feti, a marker for adequate Se levels. Forage selenium levels in both the Idaho and Montana habitats averaged 8-10 times lower than what is recommended for domestic sheep forage of 0.25 and $0.30 \mathrm{ppm}$ for whole blood levels to reach $0.2 \mathrm{ug} / \mathrm{ml}$ (Kincaid, 1998). Low blood Se levels are associated with immunosuppression (KiremidijianSchumacher \& Stotzky, 1987, Hall et al., 2011). It has been speculated that bighorn sheep may have adapted to alpine environments and do not require as much Se as domestic animals (Samson et al., 1989). However, it appears that higher dietary Se levels for bighorn sheep may enhance immune functions based upon a positive linear relationship of Se levels and glutathione peroxidase in bighorn sheep (Samson et al., 1989).

Based on the percentages of nitrogen, protein and total digestible nutrients and metabolizable energy analyses of the range forages from both bighorn habitats, nutritional components met or exceeded published requirements for domestic sheep (NRC, 1985). Although the mean percent Ca levels in the BC and SP forage were almost four times the 1985 NRC value of 0.20 listed as required for domestic sheep forage, blood and vitreous humor levels did not reflect the high forage levels but were lower than expected for domestic sheep. However, there was no evidence of poor or weak bone formation in any of the bighorn sheep that would be indicative of Ca deficiency. Dietary iron (Fe) values for both herds were more than adequate. The high values may reflect aberrant soil that contaminated the samples and would also be on forage ingested by the bighorn sheep. Dietary levels should not exceed $500 \mathrm{mg} / \mathrm{kg}$ dry forage (NRC 2005). Iron levels (540-990 mg/kg dry matter) may cause $\mathrm{Cu}$ deficiency in lambs and goats (Ivan et al. 1990). Unfortunately, blood and vitreous humor $\mathrm{Cu}$ levels were not accessed to determine if the high Fe levels in forage had a deleterious effect on $\mathrm{Cu}$ levels in the bighorn sheep as evident in the inverse relationship of these elements sometimes seen in domestic sheep (Ivan et al., 1990).

In evaluation of test results from the two bighorn populations for factors which could contribute to increased risk for respiratory disease, it is concluded that the Idaho population carried Pasteurellaceae which were more toxogenic than those isolated from the Montana population. Serology tests also indicated that the Idaho sheep had exposure to viruses associated with respiratory disease. In addition, forage Se levels for the Idaho population were significantly lower than those for the Montana population although both were lower than is recommended for domestic sheep. Since low Se levels in feeds have been demonstrated to be associated with decreased immune responses (KiremidijianSchumacher \& Stotzky, 1987, Hall et al., 2011) and forage from the Idaho bighorn sheep habitat was significantly lower than that of the Montana population, the Idaho sheep may have some immunosuppression. Identification and evaluation of virulence of microbial flora present in healthy and diseased bighorn sheep populations are 
needed to fully understand the dynamics of epizootics in Rocky Mountain bighorn sheep.

\section{Acknowledgments}

We thank Jeff Rohlman, Mike Scott, Julie Mulholland, Jim and Holly Akenson, Kurt Alt, Keith Aune, Harry Whitney, and Dr. Jerry Zaugg for their important contributions in aiding in the successful completion of complicated field work. This study was funded, in part, by the University of Idaho, Caine Veterinary Teaching Center, Idaho Fish and Game Department, Montana Fish, Wildlife and Parks Department, and the Montana Chapter of the Foundation for North American Wild Sheep.

\section{References}

1. Akenson, J. J. and Akenson, H. A. (1992) Bighorn sheep movement and summer lamb mortality in central Idaho. Northern Wild Sheep and Goat Council Proceedings 8:14-27.

2. Angen, Ø., Mutters, R., Caugant, D. A., Olsen, J. E., and Bisgaard, M. (1999) Taxonomic relationships of the [Pasteurella] haemolytica complex as evaluated by DNADNA hybridizations and 16S rRNA sequencing with proposal of Mannheimia haemolytica gen. nov., comb. nov., Mannheimia granulomatus comb. nov., Mannheimia glucosida sp. nov., Mannheimia ruminalis sp. nov. and Mannheimia varigena sp. nov. International Journal of Systematic Bacteriology 49:67-86.

3. Angen, $\emptyset$, Ahrens, P., and Bisgaard, M. (2002) Phenotypic and genotypic characterization or Mannheimia (Pasteurella) haemolytica-like strains isolated from diseased animals in Denmark. Veterinary Record 84:103-114.

4. Besser, T. E., Cassirer, E. F., Potter, K. A., Vanderschalie, J., Fescher, A., Knowles, D. P., Herndon, D. R., Rurangirwa, F. R., Weiser, G. C., and Srikumaran, S. (2008) Association of Mycoplasma ovipneumoniae infection with population-limiting respiratory disease in free-ranging Rocky Mountain bighorn sheep (Ovis canadensis canadensis). Journal of Clinical Microbiology 46:423-430.

5. Beuchner, H. K. (1960) The bighorn sheep in the United States, its past, present and future. Wildlife Monographs $4.174 \mathrm{pp}$.

6. Biberstein, E. L., Jang, S. S., Kass, P. H., and Hirsh, D. C. (1991) Distribution of indoleproducing urease-negative Pasteurellas in animals. Journal of Veterinary Diagnostic Investigation 3:319-323.

7. Bureau of Land Management. (1986) Sampling vegetation attributes. Interagency Technical Reference, National Applied Resource Sciences Center. pp. 55-63.

8. Brogden, K. A., Lehmkuhl, H. D. and Cutlip, R. C. (1998) Pasteurella haemolyticacomplicated respiratory infections in sheep and goats. Veterinary Research 29:233-254.

9. DeLong, W. J., Hunter, D. L. and Ward, A. C. S. (2000) Susceptibility of two bighorn sheep cell cultures to selected common ruminant viruses. Journal of Veterinary Diagnostic Investigation 12:261-262.

10. Dunbar, M. R. (1992) Theoretical concepts of disease versus nutrition as primary factors in population regulation of wild sheep. Northern Wild Sheep and Goat Council Proceedings 8:174-192.

11. Fisher, M. A., Weiser, G. C., Hunter, D. L., and Ward, A. C. S. (1999) Use of a polymerase chain reaction to detect the leukotoxin gene lktA in biogroup and biovariant isolates of Pasteurella haemolytica and P. trehalosi. American Journal of Veterinary Research 60:1402-1406.

12. Greer, C. N., and Shewen, P. E. (1986) Automated colorimetric assay for the detection of Pasteurella haemolytica leukotoxin. Veterinary Microbiology 12: 3342. 
13. Hall, J. A., Sendek, R. L., Chinn, R. M., Bailey, D. P., Thonstad, K. N., Wand, Y., Forsberg, W. R. Vorachek, Stand, B. V., Van Saun, R. J., and Bobe, G. (2011) Higher wholeblood selenium is associated with improved immune responses in footrot-affected sheep. Veterinary Research 42:99.

14. Ivan, M., Hidiroglou, M., al-Ismaily, S. L., alSumry, H. S., and Harper, R. B. (1990) Copper deficiency and posterior paralysis (Shalal) in small ruminants in the Sultanate of Oman. Tropical Animal Health and Production 22:217-225.

15. Jaworski, M. D., Ward, A. C. S., Hunter, D. L., and Wesley, I. V. (1993) Use of DNA analysis of Pasteurella haemolytica biotype T isolates to monitor transmission in bighorn sheep (Ovis canadensis canadensis). Journal of Clinical Microbiology 31: 831-835.

16. Jaworski, M. D., Hunter, D. L., and Ward, A. C. S. (1998) Biovariants of isolates of Pasteurella from domestic and wild ruminants. Journal of Veterinary Diagnostic Investigation 10:49-55.

17. Kelley, S.T., Cassirer, E. F., Weiser, G. C., and Safaee, S. (2007) Phylogenetic diversity of Pasteurellaceae and horizontal gene transfer of leukotoxin in wild and domestic sheep. Infection, Genetics and Evolution 7:1323.

18. Kincaid, R. (1998) The biological basis for selenium requirements of animals. The Professional Animal Scientist 11:26-29.

19. Kiremidjian-Schmacher, L., and Stotzky, G. (1987) Selenium and immune responses. Environmental Research 42:277-303.

20. Marsh, H. (1938) Pneumonia in Rocky Mountain bighorn sheep. Journal of Mammalogy 19:214-219.

21. McCollough, S. A., Cooperrider, A. Y., and Bailey, J. A. (1980) Impact of cattle gazing on bighorn sheep habitat at Trickle Mountain,
Colorado. Northern Wild Sheep and Goat Council Proceedings 2:42-59.

22. McLaughlin, P.S., and McLaughlin, B. G. (1987) Chemical analysis of bovine and porcine vitreous humors: Correlation of normal values with serum chemical values and changes with time and temperature. American Journal of Veterinary Research 48:467-473.

23. Miller, D. S., Weiser, G. C., Ward, A. C. S., Drew, M. L., and Chapman, P. L. (2012) Pasteurellaceae isolated from bighorn sheep (Ovis canadensis) from Idaho, Oregon, and Wyoming. American Journal of Veterinary Research 73:1024-1028.

24. Moore, D. S. and McCabe, G. P. (1993) Introduction to the practice of statistics. 2nd ed. W. H. Freeman and Company, New York, USA.

25. Nei, M., and Li, W. H. (1979) Mathematical model for studying genetic variation in terms of restriction endonucleases. Proceedings of the National Academy of Sciences (USA) 76: 5269-5273.

26. NRC. (1985) Nutrient requirements of sheep (6th ed.). National Academy Press, Washington D. C., USA.

27. NRC. 2005. Mineral Tolerance of Animals. 2nd rev. ed. National Academy Press, Washington, D. C., USA.

28. Parks, J. B., Post, G., Thorne, T., and Nash, P. (1972) Parainfluenza-3 virus infection in Rocky Mountain bighorn sheep. Journal of the American Veterinary Medical Association 161: 669-671.

29. Parks, J. B. and England, J. J. (1974) A serological survey for selected viral infections of Rocky Mountain bighorn sheep. Journal of Wildlife Diseases 10:107-110.

30. Post, G. (1962) Pasteurellosis of Rocky Mountain bighorn sheep (Ovis canadensis canadensis). Wildlife Disease 23:1-14. 
31. Potts, M. K. (1937) Hemorrhagic septicemia in the bighorn of Rocky Mountain National Park. Journal of Mammalogy 18:105106.

32. Queen, C., Ward, A. C. S., and Hunter, D. L. (1989) Bacteria isolated from nasal and tonsillar samples of clinically healthy Rocky Mountain bighorn and domestic sheep. Journal of Wildlife Diseases 30:1-7.

33. Robbins, C. T. (1993) Wildlife feeding and nutrition (2nd ed.). Academic Press Inc., San Diego, California, USA.

34. Rudolph, K. M, Hunter, D. L., Foreyt, W. J., Cassirer, E. F., Rimler, R. B., and Ward, A. C. S. (2003) Sharing of Pasteurella spp. between free-ranging bighorn sheep and feral goats. Journal of Wildlife Diseases 39:897-903.

35. Rudolph, K. M., Hunter, D. L., Rimler, R. B., Cassirer, E. F., Foreyt, W. J., DeLong, W. J., Weiser, G. C., and Ward, A. C. S. (2007) Microorganisms associated with a pneumonic epizootic in Rocky Mountain bighorn sheep (Ovis canadensis canadensis) Journal of Zoo and Wildlife Medicine 38:548558.

36. Ruffin, D. C. (2001) Mycoplasma infections in small ruminants. Veterinary Clinics of North America Food Animal Practice 17:315-332.

37. Rush, W. M. (1927) Notes on diseases in wild game animals. Journal of Mammalogy 8:163.

38. Samson, J., Jorgenson, J. T., and Wishart, W. D. (1989) Glutathione peroxidase activity and selenium levels in Rocky Mountain bighorn sheep and mountain goats. Canadian Journal of Zoology 67:2493-2496.

39. Schwantje, H. M. (1988) Causes of bighorn sheep mortality and dieoffs-literature review. Wildlife Working Report No. WR-35, British Columbia Ministry of Environment, Lands, and Parks, Victoria, British Columbia, Canada.
40. Shanthalingam, S., Goldy, A., Bavanathasivam, J., Subramaniam, R., Gatra, S. A., Kugadas, A., Raghavan, B., Dassanayake, R. P., Jenninga-Gaines, J. E., Killion, H. J., Edwards, W. H., Ramsey, J. M., Anderson, N. J., Wolff, P. L., Mansfield, K., Gruning,D., and Srikumaran, S. (2014) PCR assay detects Mannheimia haemolytica in culture-negative pneumonic lung tissues of bighorn sheep (Ovis canadensis) from outbreaks in the western USA, 2009-2010. Journal of Wildlife Diseases 50:1-10.

41. Shewen, P. E., and Wilkie, B. N. (1982) Cytotoxin of Pasteurella haemolytica acting on bovine leukocytes. Infection and Immunity 35:91-94.

42. Sneath, P. H. A., and Sokal, R. R. (1973) Numerical taxonomy. W.H. Freeman \& Co., San Francisco, California, USA.

43. Snedecor, G. W. (1946) Statistical methods. Iowa State University Press, Inc., Ames, Iowa, USA.

44. Spraker, T. R., Hibler, C. P., Schoonveld, G. G., and Adney, W. S. (1984) Pathologic changes and microorganisms found in bighorn sheep during a stress-related die-off. Journal of Wildlife Diseases 20:319-327.

45. Spraker, T. R., and Collins, J. K. (1986) Isolation and serologic evidence of a respiratory syncytial virus is bighorn sheep from Colorado. Journal of Wildlife Diseases 22:416-418.

46. Stabel, J. R., Spears, J. W., and Brown Jr., T. T. (1993) Effect of copper deficiency on tissue, blood characteristics, and immune function of calves challenged with infectious bovine rhinotracheitis virus and Pasteurella haemolytica. Journal of Animal Science 71:1247-1255.

47. Stelfox, J. G. (1971) Bighorn sheep in the Canadian Rockies: a history 1800-1970. Canadian Field Naturalist 85:101-122. 
48. Thorne, E. T., Kingston, N., Jolley, W., and Bergstrom, R. C. (1982) Diseases of wildlife in Wyoming. Wyoming Game and Fish Department. Cheyenne, Wyoming, USA.

49. Walsh, D. P., Wolfe, L. L., Vieira, M. E. P., and Miller, M. W. (2012) Detection probability and Pasteurellaceae surveillance in bighorn sheep. Journal of Wildlife Diseases 48:593-602.

50. Ward, A. C. S., Hunter, D. L., Jaworski, M. D., Benolkin, P. J., Dobel, M. P., Jeffress, J. B., and Tanner, G. A. (1997) Pasteurella spp. in sympatric bighorn and domestic sheep. Journal of Wildlife Diseases 33:544-557.

51. Weiser, G. C., DeLong, W. J., Paz, J. L., Shafii, B., Price, W. J., and Ward, A. C. S. (2003) Characterization of Pasteurella multocida associated with pneumonia in bighorn sheep. Journal of Wildlife Diseases 39:536-544.

52. Weiser, G. C., Drew, M. L., Cassirer, E. F., and Ward, A. C. S. (2012) Detection of Mycoplasma ovipneumonia and M. arginini in bighorn sheep using enrichment culture coupled with genus- and species-specific polymerase chain reaction. Journal of Wildlife Diseases 48:449-453. 
Table 1. Bibersteinia trehalosi biovariants isolated from bighorn sheep in the Idaho Big Creek and Montana Spanish Peak herds with test results for presence of the lktA gene and in vitro toxicity.

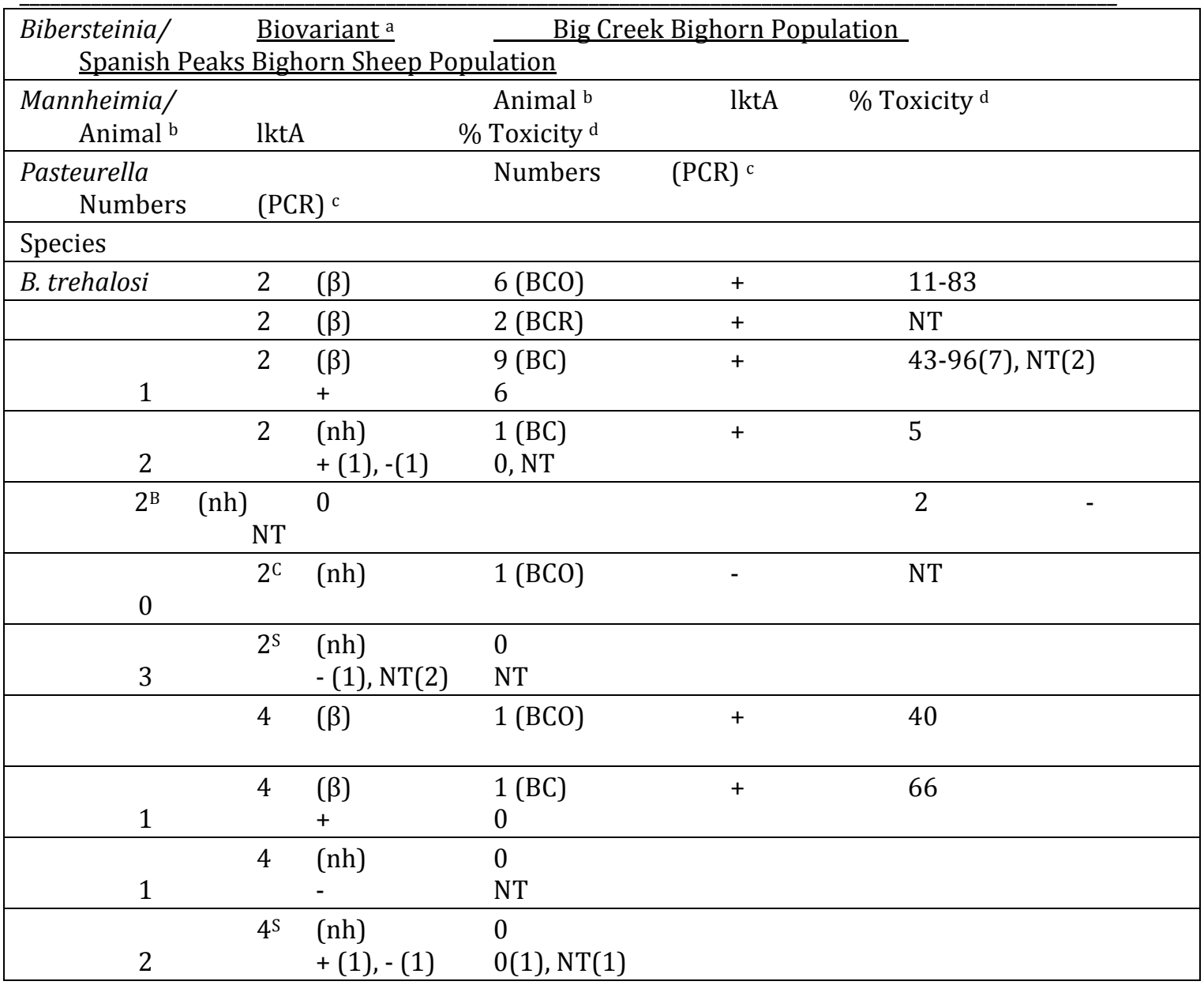

a Speciation determined by phenotypic characteristics (Angen et al., 2002). Biovariant designations determined by method of Jaworski et al., (1998). Hemolytic action on Columbia agar containing $5 \%$ domestic sheep blood comprises part of biovarinat designations, $\mathrm{nh}=$ non-hemolytic, $\beta=$ beta-hemolytic. Biovariants in shaded areas indicate those shared by bighorn sheep in both populations. ${ }^{b} \quad$ The numbers of bighorn sheep from which the listed organisms were isolated. The period when the isolates were cultured from Big Creek bighorn sheep are indicated in parentheses, i.e., $\mathrm{BCO}=1989-90$ test period when respiratory disease was detected in population, BCR for the 1994-95 test period during apparent recovery from disease episode and $\mathrm{BC}=1998-2000$ study period.

c The detection of the leukotoxin lktA gene presence determined by Polymerase Chain Reaction (Fisher et al. 1999), NT = not tested.

d Toxicity determined using bovine BL3 lymphoma cells as described by Greer and Shewen (1986).

Rebecca K. Frey, Alton C. S. Ward and Glen C. Weiser (2015), International Journal of Veterinary Medicine: Research \& Reports, DOI: 10.5171/2015.832408 
Table 2. Mannheimia species and biovariants isolated from bighorn sheep in the Idaho Big Creek and Montana Spanish Peak herds with test results for presence of the $1 k t$ A gene and in vitro toxicity.

\begin{tabular}{|c|c|c|c|c|}
\hline $\begin{array}{l}\text { Bibersteinia/ } \\
\text { Spanish P }\end{array}$ & $\underline{\text { Biovariant a }}$ & $\frac{\text { Big Creel }}{\text { Population }}$ & Bighorn P & ation \\
\hline $\begin{array}{r}\text { Mannheimia/ } \\
\text { Animal } \mathrm{b}\end{array}$ & lktA & $\begin{array}{c}\text { Animal }^{b} \\
\text { \% Toxicity } \\
\text { d }\end{array}$ & lktA & $\%$ Toxicity $\mathrm{d}$ \\
\hline $\begin{array}{l}\text { Pasteurella } \\
\text { Numbers }\end{array}$ & $(\mathrm{PCR})^{\mathrm{c}}$ & Numbers & $(\mathrm{PCR})^{\mathrm{c}}$ & \\
\hline Species & & & & \\
\hline $\begin{array}{r}\text { M. glucosida } \\
0 \\
\end{array}$ & $3 \quad(\beta)$ & $1(\mathrm{BCO})$ & + & 20 \\
\hline 2 (BCR) & + & 20 & & 0 \\
\hline $\begin{array}{r}\text { M. glucosida } \\
1\end{array}$ & $10^{\alpha \mathrm{CG}}(\mathrm{nh})$ & $\begin{array}{l}0 \\
\text { NT }\end{array}$ & & \\
\hline $\begin{array}{r}\text { M. ruminalis } \\
0\end{array}$ & $1^{\alpha \beta} \quad(\mathrm{nh})$ & 1 & + & 25 \\
\hline $1^{\alpha \beta} \quad(\beta)$ & $6(\mathrm{BC})$ & + & $19-35$ & 0 \\
\hline $\begin{array}{r}\text { M. ruminalis } \\
0\end{array}$ & $3^{\alpha E S}(\mathrm{nh})$ & $1(\mathrm{BC})$ & + & 13 \\
\hline $\begin{array}{r}\text { M. ruminalis } \\
3\end{array}$ & $\begin{array}{l}7^{\mathrm{BX}}(\mathrm{nh}) \\
-(2), \mathrm{NT}(1)\end{array}$ & $\begin{array}{l}0 \\
0(2), \operatorname{NT}(1) \\
\end{array}$ & & \\
\hline 0 & $8 \quad(\beta)$ & $1(\mathrm{BC})$ & + & 71 \\
\hline $\begin{array}{r}\text { M. ruminalis } \\
0\end{array}$ & $9^{\alpha \beta R} \quad(\beta)$ & $1(\mathrm{BC})$ & + & 16 \\
\hline 0 & $9^{\alpha \beta \mathrm{RX}}(\beta)$ & $1(\mathrm{BC})$ & + & 43 \\
\hline $\begin{array}{r}\text { M. ruminalis } \\
0\end{array}$ & $16^{\alpha \mathrm{B}}(\mathrm{nh})$ & $1(\mathrm{BC})$ & - & NT \\
\hline 2 & $\begin{array}{c}16^{\alpha \mathrm{BE}}(\mathrm{nh}) \\
+\end{array}$ & $\begin{array}{l}0 \\
27 \text { (1),NT (1) }\end{array}$ & & \\
\hline M. species & $3^{\alpha \mathrm{BE}}(\mathrm{nh})$ & $1(\mathrm{BC})$ & + & 89 \\
\hline M. species & $3^{\text {BEX }}(\mathrm{nh})$ & $1(\mathrm{BC})$ & + & 33 \\
\hline 0 & $3^{\mathrm{BX}} \quad(\beta)$ & $1(\mathrm{BC})$ & + & 4 \\
\hline 0 & $3^{\mathrm{BCX}}(\beta)$ & $1(\mathrm{BC})$ & - & NT \\
\hline $\begin{array}{r}\text { M. species } \\
0\end{array}$ & $9^{\alpha \beta \mathrm{B}}(\beta)$ & $1(\mathrm{BC})$ & + & 3.5 \\
\hline $\begin{array}{r}\text { M. species } \\
1 \\
\end{array}$ & $\begin{array}{c}10^{\alpha \mathrm{B}}(\beta) \\
+ \\
\end{array}$ & $\begin{array}{r}1(\mathrm{BCO}) \\
16 \\
\end{array}$ & + & 17 \\
\hline 1 & $\begin{array}{c}10^{\alpha \mathrm{BC}}(\beta) \\
+\end{array}$ & $\begin{array}{l}0 \\
0\end{array}$ & & \\
\hline
\end{tabular}

Rebecca K. Frey, Alton C. S. Ward and Glen C. Weiser (2015), International Journal of Veterinary Medicine: Research \& Reports, DOI: 10.5171/2015.832408 


\begin{tabular}{|c|c|c|c|c|}
\hline M. species & $\begin{array}{cl}\mathrm{U}^{\beta \mathrm{B}} & (\mathrm{nh}) \\
-\end{array}$ & $\begin{array}{l}0 \\
\text { NT }\end{array}$ & & \\
\hline 0 & $\mathrm{U}^{\beta \mathrm{BX}}(\mathrm{nh})$ & $2(\mathrm{BC})$ & - & NT \\
\hline
\end{tabular}

a Speciation determined by phenotypic characteristics (Angen et al., 2002). Biovariant designations determined by method of Jaworski et al., (1998). Hemolytic action on Columbia agar containing $5 \%$ domestic sheep blood comprises part of biovarinat designations, $\mathrm{nh}=$ non-hemolytic, $\beta=$ beta-hemolytic. Biovariants in shaded areas indicate those shared by bighorn sheep in both populations.

The numbers of bighorn sheep from which the listed organisms were isolated. The period when the isolates were cultured from Big Creek bighorn sheep are indicated in parentheses, i.e., BCO = 1989-90 test period when respiratory disease was detected in population, BCR for the 1994-95 test period during apparent recovery from disease episode and $\mathrm{BC}=1998-2000$ study period.

c The detection of the leukotoxin $l k t A$ gene presence determined by Polymerase Chain Reaction (Fisher et al. 1999), NT = not tested.

d Toxicity determined using bovine BL3 lymphoma cells as described by Greer and Shewen (1986).

Table 3. Antibody titers detected against infectious respiratory pathogens in serum collected from four groups of bighorn sheep. Titers expressed in serum dilutions indicated.

\begin{tabular}{|c|c|c|c|c|}
\hline Bighorn & \multicolumn{3}{|c|}{ Infectious agents $\mathrm{b}$} & \multirow[b]{2}{*}{ PI-3 } \\
\hline $\begin{array}{c}\text { Group }^{\mathrm{a}} \\
\text { OPP }\end{array}$ & BRSV & IBR & BVD & \\
\hline $\begin{array}{c}\mathrm{BCO}(\mathrm{n}=4) \\
\text { neg }\end{array}$ & neg & neg & neg & neg \\
\hline $\begin{array}{c}\text { BCR }(n=5) \\
\text { neg }\end{array}$ & $1: 4(n=1)$ & neg & $1: 4(n=1)$ & $1: 5(n=2)$ \\
\hline $1: 8(n=1)$ & $1: 8(n=2)$ & $1: 10(n=1)$ & $1: 16(n=2)$ & $1: 32(\mathrm{n}=1)$ \\
\hline $1: 20(n=1)$ & $1: 32(n=1)$ & & & \\
\hline $\mathrm{BC}(\mathrm{n}=13)$ & neg & neg & neg & $1: 32(\mathrm{n}=1)$ \\
\hline \multicolumn{5}{|l|}{ neg } \\
\hline SP $(n=5)$ & neg & neg & neg & $1: 8(n=1)$ \\
\hline neg & & & & \\
\hline
\end{tabular}

Bighorn groups were; BCO = bighorn sheep in Idaho Big Creek population tested during a disease epizootic in 1989 and 1990; BCR = Idaho Big Creek bighorn sheep tested during epizootic recovery period (1990-1994); BC = bighorn sheep in Idaho Big Creek population tested during the December 1998 through April 2000 and SP = Montana Spanish Peaks hunter harvested bighorn sheep tested during 1997, 1998 and 1999.

Infectious respiratory pathogenic agents: Bovine Respiratory Syncytial Virus (BRSV), Infectious Bovine Rhinotrachitis (IBR) virus, Bovine Virus Diarrhea (BVD) virus, Parainfluenza-3 (PI-3) virus and Ovine Progressive Pneumonia (OPP) virus.

Rebecca K. Frey, Alton C. S. Ward and Glen C. Weiser (2015), International Journal of Veterinary Medicine: Research \& Reports, DOI: 10.5171/2015.832408 
Table 4.-Blood or vitreous humor chemistry values of Big Creek bighorn sheep during respiratory disease epizootic (BCO), Big Creek bighorn sheep following epizootic (BC) and Spanish Peaks (SP) bighorn sheep with normal domestic sheep values NRC (1985).

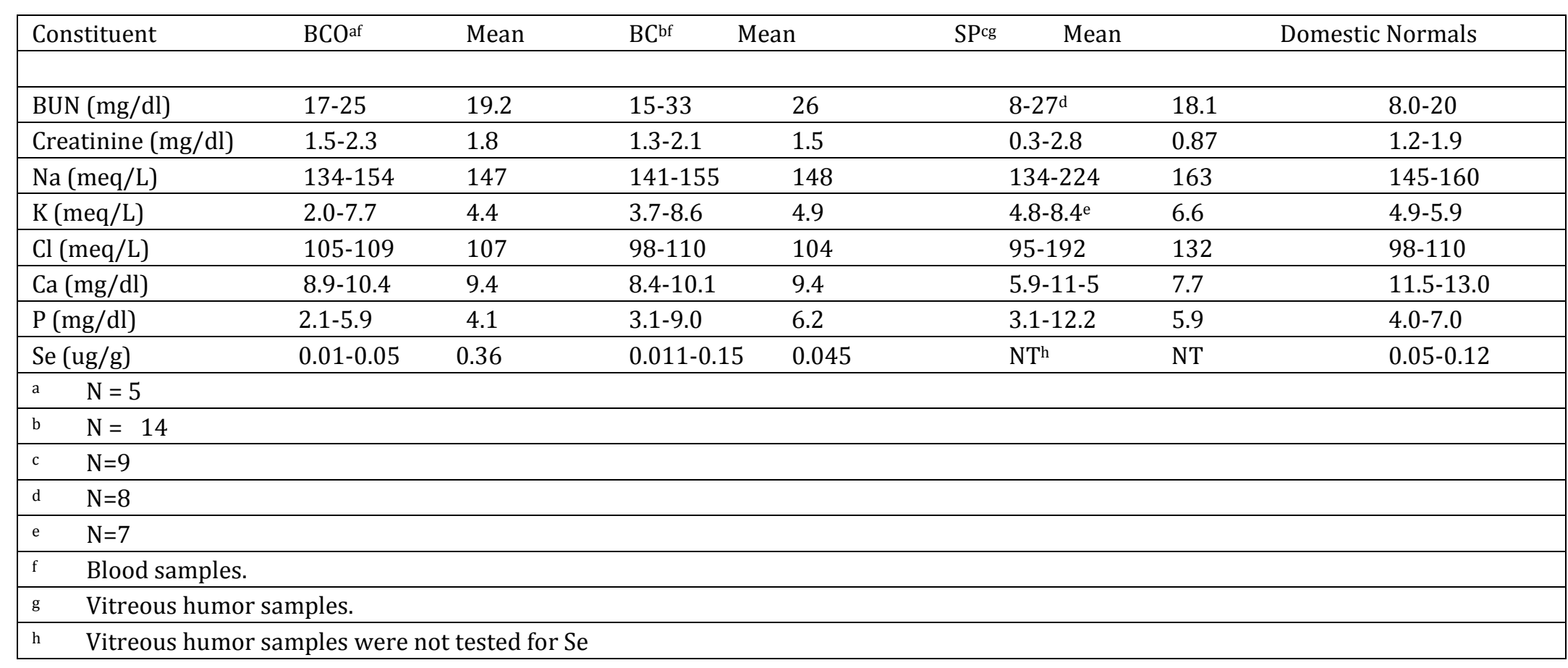


Table 5. Composition of forage on the Montana Spanish Peaks and Idaho Big Creek bighorn sheep ranges based on dry matter values.

\begin{tabular}{|c|c|c|c|c|c|}
\hline \multicolumn{2}{|r|}{ Idaho Big Creek } & \multicolumn{3}{|c|}{ Montana Spanish Peaks } & \multirow[b]{2}{*}{ Random sample } \\
\hline $\begin{array}{l}\text { Forage component } \\
\text { Required }^{1}\end{array}$ & Diet & \multicolumn{2}{|l|}{ Random sample } & Diet & \\
\hline & Mean (Range) & Mean (Range) & Mean (Range) & \multicolumn{2}{|l|}{ Mean (Range) } \\
\hline \% Nitrogen & $1.74(1.14-2.14)$ & $1.64(1.22-1.91)$ & $1.76(0.6-2.72)$ & $1.53(0.97-2.02)$ & 1.50 \\
\hline$\%$ Protein & $10.86(7.11-13.37)$ & $10.25(7.6-11.91)$ & $11.0(5.6-17)$ & $9.53(6.07-12.64)$ & 9.4 \\
\hline$\%$ Acid Detergent Fiber & $37.72(31.3-45.5)$ & $41.12(34.9-47.1)$ & $37.37(24.8-48.7)$ & $43.43(28.9-53.9)$ & $\mathrm{VD}^{2}$ \\
\hline${ }^{\%}$ Calcium & $0.75(0.5-1.3)$ & $0.72(0.58-0.9)$ & $0.81(0.4-1.7)$ & $0.87(0.61-1.09)$ & 0.20 \\
\hline \% Phosphorus & $0.25(0.16-0.31)$ & $0.25(0.13-0.31)$ & $0.18(0.12-0.3)$ & $0.17(0.12-0.27)$ & 0.20 \\
\hline \%Magnesium & $0.19(0.11-0.35)$ & $0.16(0.09-0.23)$ & $0.22(0.11-0.51)$ & $0.20(0.12-0.34)$ & $0.12-.18$ \\
\hline Zinc (ppm) & $30(23-41)$ & $32(26-40)$ & $27(22-33)$ & $40(32-43)$ & $20-33$ \\
\hline Manganese (ppm) & $91(40-165)$ & $91(30-216)$ & $98(27-141)$ & $136(76-214)$ & $20-40$ \\
\hline Copper $(\mathrm{ppm})$ & $7.8(7-8)$ & $8.3(7-10)$ & $8.5(4-12)$ & $11(6-23)$ & $7-11$ \\
\hline Iron $(\mathrm{ppm})$ & $561(78-1229)$ & $1538(100-3252)$ & $470(106-1257)$ & $1470(143-4111)$ & $30-50$ \\
\hline Selenium (ppm) & $0.027(0.012-0.05)$ & $0.024(0.02-0.028)$ & $0.035(0.03-0.04)$ & $0.043(0.024-0.052)$ & $0.1-0.2$ \\
\hline $\mathrm{TDN}^{3}(\%)$ & $59.41(50.71-66.88)$ & $55.66(48.84-62.82)$ & $59.94(46.98-74.3$ & 3) $53.03(41.09-69.56)$ & 55 \\
\hline $\mathrm{ME}^{4}(\mathrm{Kcal} / \mathrm{lb})$ & $977(832-1098)$ & $914(802-1031)$ & $984(771-1220)$ & $871(674-1142)$ & 909 \\
\hline \multicolumn{6}{|c|}{$1 \quad$ Requirements based on domestic sheep values (NRC, 1985) } \\
\hline \multicolumn{6}{|l|}{$2 \quad$ Variable Data } \\
\hline \multicolumn{6}{|c|}{$3 \quad$ Total Digestible Nutrients } \\
\hline \multicolumn{6}{|c|}{$4 \quad$ Metabolizable Energy } \\
\hline
\end{tabular}


Table 6. Comparison of mean values of vitreous humor from Montana Spanish Peaks hunter harvested bighorn sheep and mean values of normal domestic sheep with mean values of vitreous humor and blood serum of cattle collected at time of slaughter (McLaughlin and McLaughlin 1987).

\begin{tabular}{|c|c|c|c|c|c|c|}
\hline Component & SPVmean $^{\mathrm{a}}$ & DSS mean $^{b}$ & Vitreous: & Cattle $\mathrm{V}^{\mathrm{c}}$ & Cattle $\mathrm{S}^{\mathrm{d}}$ & Vitreous: \\
\hline & & \multicolumn{3}{|c|}{ Serume } & & Serum $\mathrm{f}$ \\
\hline Urea Nitrogen $(\mathrm{mg} / \mathrm{dl})$ & 18.1 & 14.0 & 1.29 & 10.3 & 12.6 & 0.82 \\
\hline Creatinine (mg/dl) & 0.87 & 1.55 & 0.56 & 0.6 & 1.3 & 0.42 \\
\hline Sodium $(\mathrm{mEq} / \mathrm{L})$ & 163.0 & 152.5 & 0.95 & 137.0 & 145.0 & 0.95 \\
\hline Potassium (mEq/L) & 6.6 & 5.4 & 1.22 & 4.6 & 6.3 & 0.73 \\
\hline Chloride (mg/dl) & 132.0 & 104.0 & 1.26 & 120.0 & 103.0 & 1.16 \\
\hline Calcium (mg/dl) & 7.7 & 12.2 & 0.63 & 5.4 & 9.9 & 0.54 \\
\hline Phosphorus (mg/dl) & 5.9 & 5.5 & 1.07 & 1.0 & 6.7 & 0.15 \\
\hline \multicolumn{7}{|c|}{ a Mean values of component in vitreous humor of SP bighorn sheep } \\
\hline \multicolumn{7}{|c|}{ b $\quad$ Mean values of component in serum of normal domestic sheep (NRC 1985) } \\
\hline \multicolumn{7}{|c|}{ c $\quad$ Mean values of component in vitreous humor of cattle collected immediately following slaughter (McLaughlin and McLaughlin 1987). } \\
\hline \multicolumn{7}{|c|}{ d $\quad$ Mean values of component in blood serum of cattle collected prior to slaughter (McLaughlin and McLaughlin 1987). } \\
\hline \multicolumn{7}{|c|}{ SP mean vitreous humor value:mean normal domestic sheep blood serum value ratios. } \\
\hline \multicolumn{7}{|c|}{ Mean bovine vitreous humor value:mean bovine blood serum value ratios (McLaughlin and McLaughlin 1987). } \\
\hline
\end{tabular}




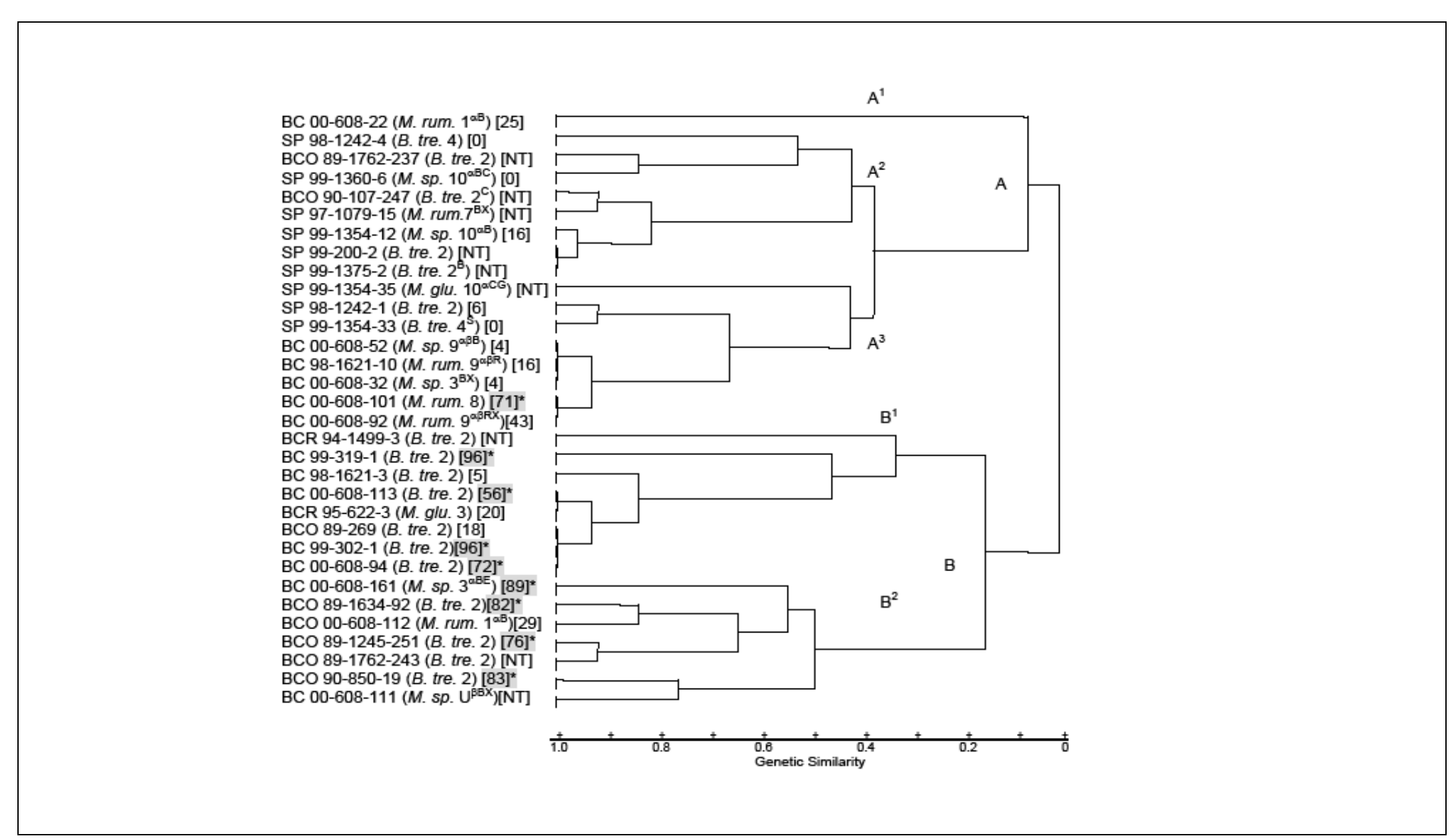

Figure 1: Genetic relationships of Mannheimia spp. and Bibersteinia trehalosi from Big Creek, Idaho and Spanish Peaks, Montana bighorn sheep herds. Shaded numbers marked with asterisks represent cytotoxicity levels over 50\%. Abbreviations: BC, Big Creek, Idaho herd isolates, 1997-2000; BCO, Big Creek, Idaho herd isolates, 1988-1990; SP, Spanish Peaks, Montana herd isolates, 1997-1990; B.tre., Bibersteinia trehalosi; M. glu., Mannheimia glucosida; M. rum., M. ruminalis; M. sp., M. species. 